\title{
Potential of Mangrove Apples (Sonneratia alba) as a Botanical Insecticide
}

\author{
Victor George Siahaya ${ }^{1}$, Trijunianto Moniharapon ${ }^{2}$, Meigy Nelce Mailoa ${ }^{2} \&$ Johanna Audrey Leatemia $^{1}$ \\ ${ }^{1}$ Faculty of Agriculture, Pattimura University, J1. Ir. M. Putuhena, Indonesia \\ ${ }^{2}$ Faculty of Fisheries and Marine Science, Pattimura University, Jl. Mr. Chr. Soplanit, Indonesia \\ Correspondence: Victor George Siahaya, Faculty of Agriculture, Pattimura University, Jl. Ir. M. Putuhena, 97234 \\ Ambon, Indonesia. E-mail: vg.siahaya@gmail.com
}

Received: November 21, $2017 \quad$ Accepted: November 30, $2017 \quad$ Online Published: December 10, 2017

doi:10.5539/mas.v12n1p1 URL: https://doi.org/10.5539/mas.v12n1p1

The research is financed by KEMENRISTEKDIKTI.

\begin{abstract}
This study aims to determine the potential of mangrove apple extract (Sonneratia alba) as a botanical insecticide. Tests were conducted to observe the bioactivity of mangrove apple extract and phytochemical tests were conducted in order to see the content of bioactive compounds. The test results showed that the mortality rate of test larva (Nezara viridula) reached $98 \%$, while the phytochemical test showed that the mangrove fruit contains phytotoxin compounds that can affect the behavior and even kill the test larvae. The compounds found are flavonoids, triterpenoids, alkaloids, tannins, steroids, phenolics, and saponins. The influence of flavonoid compounds is strong enough to attract insects.
\end{abstract}

Keywords: Sonneratia alba, mangrove, botanical insecticide, phytochemistry

\section{Introduction}

The issue of environmental pollution makes the developed countries become more alerted to the export of agricultural commodities. This can be seen by the increasingly stringent regulations relating to ecolabelling. The requirements contained therein are very difficult to be applied by businesses, government, and society as to impede the export of Indonesian agricultural products (Suwanto, 1994; Suwahyono, 1996). Global policies limiting the use of synthetic pesticides can be a barrier in the export of agricultural commodities.

The government has been instrumental in overcoming the problem of pollution of agricultural waste by applying environmentally friendly technology. Ecotechnology is one way to solve environmental problems, ie technologies that require little energy and produce waste as little as possible or without waste at all (Said, 1994; Utami \& Rahyu, 1996).

The government has made a regulation confirming that in the context of controlling plant-disturbing organisms, the use of synthetic insecticides should be chosen as the last alternative, as well as the impacts arising from the use of these synthetic chemicals should be considered as early as possible and should be minimized (Anonimous, 2016). Therefore, the policy of utilizing environmentally friendly vegetable materials is the right choice to build future agriculture (Syakir, 2011). This illustrates that it is time for the utilization of botanical insecticides to be very important in producing agricultural products that meet the requirements.

Potential mangrove plants and their associations for disease prevention in shrimp and fish have been reported (Dhayanithi et al., 2012; Soonthornchareonnon et al., 2012). Some mangrove plants are known to contain bioactive compounds that can be used as antibacterial species such as Rhizophora mucronata (Baskaran and Mohan, 2012), Excoecaria agallocha L. (Prakash and Sivakumar, 2013). In addition to being antibacterial, mangroves are also reported as immuno stimulant ingredients in fish (Avendo \& Serrano, 2012; Dhayanithi et al., 2012).

The extract of the calyx and fruit of Sonneratia alba has been reported to have potential as an antibacterial natural compound against the pathogens of tiger shrimp Vibrio harveyi (Naiborhu, 2002; Maryani et al., 2002). Sonneratia alba fruit extracts are known to contain secondary metabolites in the form of alkaloids, flavonoids and tannins that act as antifungal and inhibit the development of Helminthosporium sp (Kusumadewi et al., 2014). Herawati (2011) 
reports from her research that Sonneratia alba has great potential as a source of natural antioxidants, and confirms its function in traditional use as a preservative and wound medicine. On the other hand, information about the use of Sonneratia alba as a botanical insecticide has never been present, except as antibacterial and antifungal.

Botanical insecticide is an insecticide whose base material is derived from plants, and has an active ingredient that can control insect pests. In 1690, farmers in France used tobacco leaf juice to control ladybugs on peaches. In 1800, powdered pyrux plants were used to control aphids (Chan-Bacab and Pena-Rodriguez, 2001; Biebel et al., 2003). The use of botanical insecticides in addition to reducing environmental pollution, is also cheaper compared to chemical insecticides (Zhu et al., 2001; Auger et al., 2004; Wiratno et al., 2009; Wiratno et al., 2011).

Evolutionally, plants have developed and produced natural chemicals as a means of self-defense against annoying insects. Plants contain chemicals in the form of secondary metabolite compounds whose functions in the metabolic processes of plants are still less clear. However, this group of compounds apparently plays an important role in the process of interacting or competing, including protecting themselves from the disruption of its competitors (Kardinan and Wikardi, 1994). These secondary metabolites can be utilized as active ingredients of plant insecticides (Kardinan and Wikardi, 1997; Dubey et al., 2008) and are also used by plants as a means of defense against invasive organism attacks.

Although only about 10,000 types of secondary metabolites have been identified, the amount of potential plantbased chemicals as botanical insecticides is estimated to be at 400 thousand species (Grainge and Ahmed, 1988; Aranillewa et al., 2006). It is estimated there are about 1,800 species of plants containing botanical insecticides that can be used for pest control. In Indonesia, plant species produce botanical insecticides are spread in 235 families with 2,400 plant species (Kardinan, 2011).

Basically, the natural ingredients that contain bioactive compounds can be classified into three, the natural ingredients with the content of the compound is anti-phytopathogenic (agricultural antibiotics), phytotoxic or regulate the growth of plants (phytotoxins, plant hormones and the like), and natural ingredients with compounds which are active against insects (insect hormones, pheromones, antifeedants, repellents, attractants, and insecticides) (Takahashi, 1981). In general, the mechanism of action of botanical insecticides in protecting plants from plant-disturbing organisms directly inhibits the reproduction process of insect pests, especially female insects, reduces appetite, causes insects to resist food, destroys the development of eggs, larvae and pupa so that the breeding of insect pests is disrupted, and the changing of skin. (Takahashi, 1981) classified botanical insecticides based on the workings of the repelen group, ie, rejecting the presence of insects eg odorous odors, antifidan groups that can prevent insects from eating sprayed plants, inhibiting the reproduction of female insects, as neurotoxin and can disrupt the hormone system in the insect's body, the attractant group, which is a botanical insecticide that can lure the presence of insects so that it can serve as an insect trap and also to control the growth of fungi/bacteria, and botanical insecticide groups that decrease the preference of insects in accessing food sources.

The advantages of botanical insecticides are: 1) the technology required to produce it is easy and cheap, so that it can be made on a household scale; 2) does not cause negative effects to the environment and living creatures, so it is relatively safe to use; 3 ) no risk of poisoning to the plant, so the plant is healthier and safe from the contamination from harmful chemicals; 4 ) does not cause resistance to pests so that it is safe for ecosystem balance; and 5) is a healthier agricultural product and free from chemical insecticide residues (Suriana in Hidayanti and Ambarwati, 2016; Yusuf, 2012).

The disadvantages of botanical insecticides are: 1) the power is slow, can not be seen in the immediate time; 2) generally does not kill the target pest directly, but merely discharges and causes the pest to be uninterested in the cultivation crop; 3) easily damaged and not resistant to sunlight; 4) shelf life is relatively short so it must be used immediately after production and this becomes a bottleneck in commercially producing botanical insecticides; 5) need repeated spraying so that the economic side is ineffective and efficient (Suriana in Hidayanti and Ambarwati, 2016; Yusuf, 2012).

This study aims to determine the potential of apple mangrove extract (Sonneratia alba) as a botanical insecticide. Tests conducted is to see the bioactivity of mangrove fruit extract and phytochemical test to see the content of bioactive compounds.

\section{Methods}

\subsection{Materials and Tools}

The materials used were powder of mangrove apples, methanol, hexane, ethyl acetate, $\mathrm{HgCl}$, KI, salicylic acid, I2, Bi (NO3) 3, concentrated $\mathrm{HNO} 3$, concentrated $\mathrm{H} 2 \mathrm{SO} 4, \mathrm{FeCl}$, concentrated $\mathrm{HCl}, \mathrm{Mg}$ band, acetic acid anhydrate, $\mathrm{NaCl}$, gelatin, ammonia and aquades, test insects Nezara viridula (3rd instar). 
Equipment used: beaker, measuring cup, large vial, measuring flask, spatula, glass funnel, Buchner filter set, rotary vacuum evaporator, digital weighing, sprayer, capillary pipe, dropper pipette, volumetric papier, electric bath, gauze, petri dish, knife.

\subsection{Time and Place}

The research was conducted in Plant Pest Laboratory of Faculty of Agricultural and Organic Chemistry Laboratory of Faculty of Mathematics and Natural Sciences, Pattimura University, Ambon, Mollucas-Indonesia. The study runs from May 2017 to completion.

\subsection{Preparation of Mangrove Apples (Sonneratia alba)}

Samples of mangrove apples ( $S$. alba) collected are cleaned from the impurities attached, then cut into small pieces, then dried in the wind or air. The dried samples are then ground to a fine powder ready to be macerated.

\subsection{Stages of Extraction}

The fine powder of mangrove apple ( $S$. alba) was 20 grams macerated with methanol, hexane, and ethyl acetate solvents with a solvent height of $\pm 1 \mathrm{~cm}$ above the sample. Maseration was allowed for 24 hours at room temperature. The maseration results were filtered using a Buchner filter and the obtained filtrate was vacuum evaporated using a rotary vacuum evaporator to obtain a viscous extract.

\subsection{Bioactivity Extracts}

The test extract was diluted with methanol until an extract solution of $10 \%$ was obtained. The feed to be used was smeared with a solution of methanol extract, hexane, and ethyl acetate, then placed into a tissue box, then inserted with 10 insect Nezara viridula (3rd instar). The feed on the control was only smeared with methanol alone. The feeding of treated leaves was for 48 hours, then the feed was replaced with fresh feed without treatment. Insect mortality tests were performed every 24 hours until the larvae reached the 4th instar. Extracts showing the highest mortality rates were subsequently tested. This research uses Completely Randomized Design with three replications.

Insect mortality is calculated as follows:

$$
M=\frac{a}{b} \times 100 \%
$$

$$
\begin{aligned}
& \mathrm{M}=\text { Insect mortality } \\
& \mathrm{a}=\text { number of dead insects } \\
& \mathrm{b}=\text { number of insects used } \\
& \text { 2.6 Phytochemical Test }
\end{aligned}
$$

\subsection{Phytochemical Test}

Manginal fruit extract of Sonneratia alba from different solvents was analyzed by alkaloid, saponin, tannin, flavonoid, steroid, triterpenoids, phenolic, tested with the steps proposed by Harborne (1998) as follows:

Test alkaloid content. A ml of mangrove Sonneratia alba extract from methanol solvent, hexane, ethyl acetate was each inserted into a test tube and combined with 5 drops of concentrated ammonia. After that, filtered and then added $2 \mathrm{ml}$ of $2 \mathrm{~N}$ sulfuric acid and shaken to give top and bottom layers. The solution was divided into 3 parts, in the first tube 1 drop of Mayer reagent was added. The presence of alkaloids was characterized by the formation of precipitate. In the second tube with 1 drop of Dragendorff reagent added, the formation of the precipitate indicated the presence of alkaloids. The third tube with 1 drop of Wagner reagent added, the formation of brown precipitate indicated the presence of alkaloids.

Test for phenolic content. $1 \mathrm{ml}$ of mangrove Sonneratia alba extract from methanol solvent, hexane, ethyl acetate was each dripped on a porcelain pellet. Then combined with methanol and stirred until homogeneous. After that, $\mathrm{FeCl}_{3}$ was added. The presence of phenolics was characterized by the formation of green, yellow, orange, or red.

Test for flavonoid content. $1 \mathrm{ml}$ of mangrove Sonneratia alba extract from methanol solvent, hexane, ethyl acetate was each inserted into a test tube. Then combined with 5 drops of ethanol and shaken until homogeneous. After that, coupled with $\mathrm{Mg}$ band and 5 drops of concentrated $\mathrm{HCl}$. If it produced yellow, orange, and red colors there was an indication of the presence of flavonoids.

Test of tannin content. $1 \mathrm{ml}$ of mangrove Sonneratia alba extract from methanol solvent, hexane, ethyl acetate was each inserted into a test tube. Then combined with 5 drops of $10 \% \mathrm{NaCl}$, and shaken until homogeneous. After 
it was filtered, the resulting filtrate was added with $1 \%$ gelatin and $10 \% \mathrm{NaCl}$. The formation of sediment indicated the presence of tannins.

Test for the content of steroids and triterpenoids. $1 \mathrm{ml}$ of mangrove Sonneratia alba extract from methanol solvent, hexane, ethyl acetate was each inserted into a test tube.Then coupled with anhydrous acetic acid and concentrated sulfuric acid. If it turned a blue or green color then it indicated the presence of steroids. If it turned a purple or orange color it indicated a triterpenoid.

Test for the content of saponins. A total of $1 \mathrm{ml}$ of mangrove Sonneratia alba extract from methanol solvent, hexane, ethyl acetate was each inserted into a test tube. Then combined with $2 \mathrm{ml}$ of aquades, then shaken until homogeneous. After that, heated for 2-3 minutes. Finally, it was chilled and shaken strongly after cold. The presence of a stable foam for 30 seconds indicated a sample containing saponins.

\section{Results and Discussion}

\subsection{Bioactivity}

Based on the mortality of the test larvae at a concentration of $10 \%$, it was found that the methanol extract was higher than the hexane and ethyl acetate extracts.

The results showed that not all extracts showed strong insecticidal activity against the test larvae. Methanol extract showed stronger insecticidal activity than hexane and ethyl acetate extracts. Treatment of methanol extract at $10 \%$ concentration resulted in $98 \%$ mortality, while in hexane and ethyl acetate extracts showed insecticidal activity that was less strong, which caused mortality of $28.4 \%$ and $44.5 \%$ (Table 1 ).

Table 1. The lethal effect of mangrove Sonneratia alba extract on larvae of Nezara viridula at concentration of $10 \%$

\begin{tabular}{lll}
\hline Exstract & Number of Larvae & Mortality* (\%) $^{\text {a }}$ \\
\hline Metanol & 10 & $98^{\mathrm{a}}$ \\
Ethyl acetate & 10 & $44.5^{\mathrm{b}}$ \\
Hexane & 10 & $28.4^{\mathrm{c}}$ \\
Control & 10 & $0^{\mathrm{c}}$ \\
\hline
\end{tabular}

*Observation stopped after larvae reached 4th instar

*Numbers followed by different letters show no significant difference

The high mortality of test larvae from methanol extract treatment showed that the active compound on methanol extract had stronger insecticidal activity than in hexane and ethyl acetate extract.

\subsection{Phytochemical Test}

Phytotoxins are compounds present in plants that are usually secondary metabolites. These compounds serve as a survival (survival) for plants and other benefits that can provide health to the human body (Hasler, 1998). Secondary metabolite compounds are used by plants for existence and survival.

Phytochemical tests conducted in this study was to test the content for flavonoids, tannins, saponins, steroids and alkaloids referring to the method of Harborne (1998). Table 2 shows the results of phytochemical screening tests on samples of mangrove apple Sonneratia alba extract by using different solvents of polarity.

Table 2. Phytochemical screening test of mangrove Sonneratia alba extract with different solvent polarity

\begin{tabular}{lccc}
\hline \multirow{2}{*}{ Secondary Metabolites } & \multicolumn{3}{c}{ EXTRACT } \\
\cline { 2 - 4 } & Methanol & Hexane & Ethyl acetate \\
\hline Alkaloid & + & + & + \\
Phenolic & + & - & + \\
Flavonoid & + & + & + \\
Tanin & + & - & + \\
Steroid & + & - & + \\
Triterpenoid & + & + & + \\
Saponin & + & - & - \\
\hline
\end{tabular}


Phytochemical test results of mangrove $S$. alba extract with various solvents showed that there were bioactive compounds in which indicated the presence of phenolic compounds, flavonoids, tannins, alkaloids, saponins, steroids or triterpenoids as in the table.

From the table above it can be seen that the compounds that are identified or not identified in mangrove apples can be explained as follows. The results of phytochemical screening tests on methanol extracts can identify phenolic compounds, flavonoids, tannins, saponins, steroids or triterpenoids, except for alkaloid compounds. The hexane extract can only identify the compounds alkoloid, triterpenoid, and flavonoids alone, while saponins, tannins, steroids and phenolic compounds are not identified. The ethyl acetate extract can only identify phenolic compounds, flavonoids, tannins, alkaloids, steroids or triterpenoids, while saponin compounds are not identified.

Alkaloid compounds. During the test for alkaloid compounds dropped with 3 reagents namely Meyer reagent, Dragendrof reagent and Wagner reagent. For the alkaloid compounds of the Meyer reagents, it is thought nitrogen in the alkaloids would react with the $\mathrm{K}+$ metal ions from the tetraiodomerkurat (II) potassium to form a sedimentlined alkaloid complex. In the reaction using Wagner reagents, it is explained that the $\mathrm{K}+$ metal ion formed a covalent coordination bond with the alkaloids to form a precipitated potassium-alkaloid complex. In the reaction using Dragendorf reagents, it is stated that the $\mathrm{K}+$ metal ion forms a covalent coordination bond with the alkaloids to form a precipitated potassium-alkaloid complex. The presence of each alkaloid was characterized by the formation of white, brown, and orange deposits. In the results of phytochemical screening test extract on mangrove apples there were alkaloid compounds (Reagent Dragendorf and Wagner) on all solvents, which arose brownish green color and there was sediment on alkaloids. The toxicity of plant alkaloids can vary greatly, generally affecting nerve or cell replacement (Mithöfer and Boland in Matsuura and Fett-Neto, 2015).

Phenolic compounds. Extracts on mangrove fruit are tested positive for phenolic compound test if green, red, yellow, orange, blue or black occur. Only methanol and ethyl acetate extracts alone contain phenolic compounds. The colors are different on each extract. In the methanol extract, a blue color appears that indicates a positive positive phenolic compounds. For ethyl acetate extract, yellow color indicates positive for phenolic compound, while the hexane negative extract of phenolic compound characterized by the occurrence of brown color.

Flavonoid compound. To know extract test containing flavonoid compound used shinoda test test, that is using $\mathrm{HCl}$ solution. The results of phytochemical screening of extracts on mangrove fruit showed that flavonoid compounds were present in all extracts with different colors. The color on the extract of methanol and hexane is yellow, whereas in purple ethyl acetate extract. If it produces yellow, orange, and red colors indicate the presence of flavonoids (Harborne, 1998). Flavonoids play a role in the provision of color, flavor and taste to fruits, flowers and seeds, as the attractant of insects, birds or mammals (Koes and Quattrocchio in Mierziak et al., 2014). In addition, it can also be repellent against insects because it has a bitter taste (Sastrohamidjojo, 1996).

Tannin compound. On tanin test mangrove extract showed positive results if characterized by the presence of yellow deposits. From the results of phytochemical screening test extract on mangrove apple extract, only tannin compound was found in the extract with methanol solvent and ethyl acetate was characterized by the emergence of greenish yellow color and the presence of sediment. In the hexane solvent there was no precipitate, so the tannin was negative in this solvent. In general, plants containing tannins are avoided by herbivores because they have an unpleasant taste (Sastrohamidjojo, 1996).

The steroid/triterpenoid compound. A widely used test for steroid/triterpenoid content is Liebermann-Burchard which with most sterols and triterpen gives blue, red and green. The result of phytochemical extract test on mangrove apple extract found triterpenoid compound on the three solvents with the appearance of red color, whereas steroid compound found only contained in methanol and ethyl acetate solvent giving blue and dark blue color.

Saponin compounds. Mangrove apple extracts were tested using the Forth method. The presence of froth in the Forth test indicated the presence of glycosides in the extract that have the ability to form foam in water that is hydrolyzed into glucose and other compounds. Saponin tests showed positive results where after shaken and left alone formed a stable foam / that persisted for 2-4 minutes. From the test results on methanol extract alone there was also foam, this proved the discovery of saponin compounds. The resulting color was green for ethyl acetate solvent, while the hexane solvent was yellow. Chaieb (2010) in his report suggested that saponins play a role as an feeding inhibitor (antifeedant) for insects. The occurrence of rejection by an insect can be caused by the absence of a feeding compound or vice versa because it contains a food-repellent compound (Perry et al.,; Schoonhoven et al., in Syahputra, 2005).

The compounds found in phytochemical tests, namely alkaloids, phenolics, flavonoids, tannins, steroids, 
triterpenoids, and saponins. Bandaranayake (2002) suggests that Sonneratia alba contains alkaloid group compounds, phenolics, steroids and terpenoids. These compounds have important toxic, pharmacologic, and ecologic effects.

From observations on the first day, it appeared that almost all insects came to the available feed, in contrast to what happened to the control. Tan dan Nishida (2012) suggests that insects will get special signals from the plants they visit with secondary metabolites that are released. It is suspected that mangrove apple extract contains compounds that act as attractants. Takahashi (1981) classifies attractant as well as a botanical insecticide that can attract insects, which can serve as insect trap compounds.

\section{Conclusion}

1. The secondary metabolite content found from phytochemical test results was, alkaloids, phenolic, flavonoids, tannins, steroids, triterpenoids, and saponins. The overall compound found was phytotoxin with positive affects of which can disrupt and even kill insect pests.

2. It is suspected that the influence of flavonoid compounds is strong enough to attract insects.

3. Apple mangrove fruit Sonneratia alba has the potential to be developed as a botanical insecticide.

\section{References}

Anonimous. (2016). Government Regulation No. 6/1995 About Plant Protection. Menteri Sekretaris Negara Republik Indonesia, Jakarta.

Aranillewa, S. T., Ekrakene, T., \& Akinneye, J. O. (2006). Laboratory Evaluation of Four Medicinal Plants as Protectants Againts The Maize Weevil, Sitophilus zeamais (Motsch). Afr. J. Biotechnol, 5(21), 2032-2036. https://doi.org/10.5897/AJB06.306

Auger, J., Arnault, I., Diwo-Allain, S., Ravier, M., Molia, F., \& Pettiti, M. (2004). Insecticidal and Fungicidal Potential of Allium Substances as Biofumigants. Agroindustria, 3, 5-8.

Avendo, P., \& Serrano, A. E. (2012). Effect of The Aplle Mangrove (Sonneratia caseolaris) on Antimicrobial, Immunostimula-tory, and Histological Responses in Black Tiger Shrimp Postlarvae Fed at Varying Feeding Frequensy. ACCL BIOFLUX, 5(3), 112-123.

Bandaranayake, W. M. (2002). Bioactivities, Bioactive Compounds and Chemical Constituents of Mangrove Plants. Wetlands Ecology and Management, 10, 421-452. https://doi.org/10.1023/A:1021397624349

Baskaran, R., \& Mohan, P. M. (2012). In Vitro Antibacterial Activity of Leaf Extracts of Rhizophora mucronata L. Against Multi Drug Resisten Vibrio spp. Isolated From Marine Water Lobster's Larvae Hatcheries. Indian Journal of Geo-Marine Science, 41(3), 218-222.

Biebel, R., Rametzhofer, E., Klapal, H., Polheim, D., \& Viernstein, H. (2003). Action of Pyrethrum-based Formulations Against Grain Weevils. Int'l. J. Pharmaceutics, 256(1-2), 175-181. https://doi.org/10.1016/S0378-5173(03)00075-9

Chaieb, I. (2010). Saponins as Insecticides: A Review. Tunisian Journal of Plant Protection, 5, 39-50.

Chan-Bacab, M. J., \& Pena-Rodriguez, L. M. (2001). Plant Natural Products With leishmanicidal Activity. Nat. Products Rep., 18, 674-688.

Dhayanithi, N. B., Kumar, T. T. A., Balasubramanian, T., \& Tissera, K. (2013). A Study on The Effect of Using Mangrove Leaf Extracts as a Feed Additive in The Progress of Bacterial Infections in Marine Ornamental Fish. Journal of Coastal Life Medicine, 1(3), 217-224. https://doi.org/10.12980/JCLM.1.20133D317

Dubey, N. K., Srivastava, B., \& Kumar, A. (2008). Current Status of Plant Products as Botanical Pesticides in Storage Pest Management. J. Biopesticides, 1(02), 182-186.

Grainge, M., \& Ahmed, S. (1988). Handbook of Plants with Pest-Control Properties. John Wiley \& Sons, New York-Chichester-Brisbane-Toronto Singapore. pp. 99-153.

Harborne, J. B. (1998). Phytochemical Methods: A Guide to Modern Techniques of Plant Analysis (3rd Ed). Chapman and Hall, London.

Hasler, C. M. (1998). A New Look at An Ancient Concept. Chem. Industry Feb., 2, 84-89.

Herawati, N. (2011). Identification of Bioactive Compound from Mangrove Trees Sonneratia alba. Jurnal Chemica, 12(1), 9-13.

Kardinan, A. D., \& Wikardi, E. A. (1994). Effect of Waste of Lemongrass Kitchen Waste and Garlic Flour Against 
the Warehouse Pest Callosobruchus analis. Buletin Penelitian Tanaman Rempah dan Obat, 9(1), 3-7.

Kardinan, A. D., \& Wikardi, E. A. (1997). Effect of Tuba Root Extract on Imago and Egg From Callosobruchus analis. Jurnal Penelitian Tanaman Industri, 3(1), 13-19.

Kardinan, A. (2011). The Use of Botanical Pesticides as Local Wisdom in The Control of Plant Pests to The Organic Farming System. Pengembangan Inovasi Pertanian, 4(4), 262-278.

Kusumadewi, T., Khotimah, S., \& dan Yanti, A. H. (2014). Fruit Methanol Extract from Sonneratia alba J.E.Sm as Growth Inhibitor for Helminthosporium sp Which Isolated from Corn Leaves. Biology Study Program, Faculty of Mathematics and Natural Sciences, Tanjungpura University. Jurnal Protobiont, 3(2), 149-154.

Maryani, D. D., \& dan Sukenda. (2002). The Role of Calyx and Fruit Extract of Mangrove Sonneratia caseolaris (L) on Infection by Bacteria Vibrio harveyi in Shrimp (Penaeus monodon Fab.). Jurnal Akuakultur Indonesia, 1(3), 129-138. http://dx.doi.org/10.19027/jai.1.129-138

Matsuura, H. N., \& Fett-Neto, A. G. (2015). Plant Alkaloids: Main Features, Toxicity, and Mechanisms of Action. Springer. Netherlands. https://doi.org/10.1007/978-94-007-6728-7_2-1

Mierziak, J., Kostyn, K., \& Kulma, A. (2014). Flavonoids as Important Molecules of Plant Interactions with the Environment. Molecules, 19, 16240-16265. https://doi.org/10.3390/molecules 191016240

Naiborhu, P. E. (2002). Extraction and Benefits of Mangrove Extract (Sonneratia alba and Sonneratia caseolaris) As Antibacterial Natural Material on Windu Shrimp Patogen Vibrio harveyi (Unpublished Thesis). Program Pascasarjana. Institut Pertanian Bogor.

Prakash, M., \& Sivakumar, L. (2013). A Study on Antibacterial Activity of Mangrove Plant Excoecaria agallocha L. International Journal of Current Microbiology and Applied Sciences, 2(8), 260-262.

Said, E. G. (1994). The Negative Effects of Pesticides, A Note for All of Us. Agrotek, 2(1), 71-72.

Sastrohamidjojo, H. (1996). Natural Material Synthesis. Gadjah Mada University Press, Yogyakarta.

Soonthornchareonnon, N., Wiwat, C., \& Chuakul, W. (2012). Biological Activities of Medicinal Plants from Mangrove and Beach Forests. Mahidol University Journal of Pharmaceutical Science, 39(1), 9-18.

Suwahyono, U. (1996). Application of Biofungicide Trichoderma spp To Control of The Pathogenic Fungi Rhizoctonia solani on Soybean Plant (Glycine max (L.) Merr.). Alami, 1(2), 50-53.

Suwanto, A. (1994). Microorganisms for Biocontrol: Research Strategies and Their Application in Agricultural Biotechnology. Agrotek, 2(1), 40-46.

Syakir, M. (2011). Status of Botanical Pesticide Research. National Seminar of Botanical Pesticide. Center for Plantation Research and Development, Bogor.

Syahputra, E. (2005). Bioactivity of Botanical Insecticide Callophylum soutary Byrm I. (Clusiaceae) As Alternative Pest Control (Unpublished Doctoral Dissertation). Sekolah Pasca Sarjana IPB.

Tan, K. H., \& Nishida, R. (2012). Methyl Eugenol: Its Occurrence, Distribution, and Role in Nature, Especially in Relation to Insect Behavior and Pollination. J. Insect Sci., 12(56), 1-74. https://doi.org/10.1673/031.012.5601

Takahashi, N. (1981). Application of Biologically Natural Products in Agricultural Fields. In M. Wirahadikusumah and A.S. Noer (Eds.). Proc. Regional Seminar on Recent Trend in Chemistry of Natural Product Research. pp. 110-132. Penerbit ITB, Bandung.

Utami, A., \& dan Rahyu, B. (1996). Ecotechnology as A Way Out to Solve Environmental Problems. Alami, 1(2), 54-57.

Wiratno, D., Taniwiryono, H., Berg, J. A. G., Riksen, I. M., Rietjens, C. M., Djiwanti, R., Kammeng, J. E., \& Murk, A. J. (2009). Nematicidal Activity of Plant Extracts Against the Root-knot Nematode, Meloidogyne incognita. The Open Natural Products J., 2, 63-71. https://doi.org/10.2174/1874848100902010077

Wiratno, M., Rizal, \& dan Laba, I. W. (2011). Potential of Medicinal and Aromatic Plant Extracts as Keong Mas Controller. Buletin Littro, 22(1), 54-64.

Yusuf, R. (2012). Potential and Obstacles to Utilize Botanical Pesticides in Pest Control on Organic Vegetable Cultivation. Seminar UR-UKM ke-7. Optimization of Science and Technology Research in Sustainable Development.

Zhu, B. C. R., Henderson, G., Chen, H. F., \& Laine, R. A. (2001). Evaluation of Vetiver Oil and Seven Insect- 
active Essential Oils Against The Formosan Subterranean Termite. J. Chem. Ecol., 27, 1617-1625.

\section{Copyrights}

Copyright for this article is retained by the author(s), with first publication rights granted to the journal.

This is an open-access article distributed under the terms and conditions of the Creative Commons Attribution license (http://creativecommons.org/licenses/by/4.0/). 